\title{
再利用資源を代替炭素源とする 浸出水の脱窒技術の実験的検討 EXPERIMENTAL STUDY ON DENITRIFICATION OF A LANDFILL LEACHATE BY USING ALTERNATIVE CARBON SOURCES
}

\author{
井上晃介 1 - 黒田將嵩 $2 \cdot$ 道奥康治 $3 \cdot$ 中道民広 4 ・八木正博 5 \\ Kosuke INOUE, Masataka KURODA, Kohji MICHIOKU, \\ Tamihiro NAKAMICHI and Masahiro YAGI

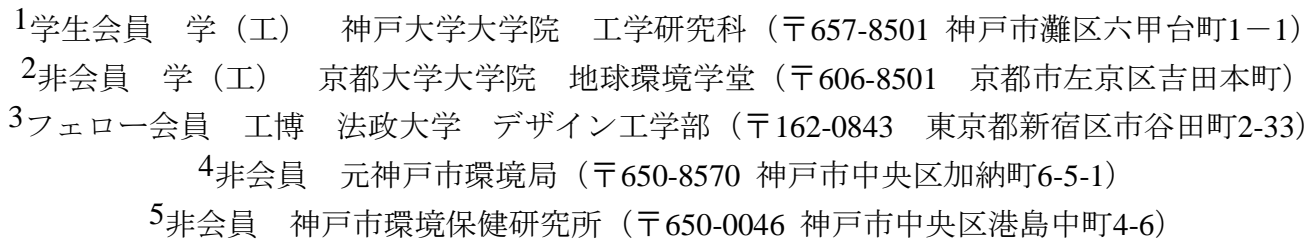

In order to develop an alternative denitrification system for purification of leachate from a municipal waste landfill, a laboratory experiment was carried out. Denitrification performance using alternative carbon resources in place of methanol was experimentally investigated in a laboratory tank. The carbon sources under investigation were hydrogen feeding agents, beer lees and solidified food oil. Hydrogen feeding agents and solidified food oil showed higher denitrification performance than the beer lees. The water quality model was verified by comparing the analytical solutions with the laboratory data using hydrogen feeding agents as carbon source. Time-dependent behaviors of every water quality component observed in the experiment were very well reproduced by the model. The analysis showed that the hydrogen feeding agent was found to be a very promising material for efficiently removing nitrogen from seriously contaminated leachate.

Key Words : nitrogen load, leachate runoff, municipal waste, denitrification, carbon source

\section{1.はじめに}

わが国は高度経済成長の見返りとして大量の産業・一 般廃棄物を生み出し，焼却処理の追いつかない余剩廃棄 物は未処理のまま最終処分場へ埋め立てられた。特に, 内陸の埋立地からは降水の浸透・流出によって, 窒素等 の栄養塩類を高濃度に含む污染水が地下水や河川など公 共用水域一及ぼす影響が懸念され，流域圈の水環境管理 上の課題となっている. こうした環境負荷の緩和の暫定 対策として, 浸出水処理施設が廃棄物処分場に併設され ているが，多くの施設が老朽化し，処理水準を維持する ことが困難となっている．本研究で対象とする埋め立て 処分場では，処理施設の廃止の目安となる環境省排水基 準のT-N=60mg/程度にまで浸出水の窒素負荷が減少しつ つある（図-1）。しかし，河川・湖沼の生態系に深刻な 影響を及ぼさない窒素濃度（1.0mg/l）1)までには至らず 現行の処理施設を廃止できない状況にある．また，図-2 に示寸ように，宅地開発が進んでいたH22-25年の間には 浸出水の流出率が平年時の数倍に増大し, 周辺の社会条 件など環境負荷を変動させる不規則要因が残る，廃棄物 処分場によっては基準を越える環境負荷が今後も中長期 にわたり継続する可能性があり，省力的で持続可能な排 水処理技術の確立が必要である.

一般に，埋立地からの浸出水が還元的環境にある地盤 を通過する間に，大部分のリンや䀣濁態有機物が吸着・ 除去されているため, アンモニア態窒素を主成分とする 一般下水とは非常に異なった水質構成を有している。こ れまで，著者らは新しい窒素除去システムとしてマイク ロバブル曝気による硝化 ${ }^{2)}$, 3)，水素徐放剂による脱窒4)を 実験的・理論的に検討してきた．脱窒処理には微生物の 活動栄養源として炭素が必要となり, 現行の処理施設で 


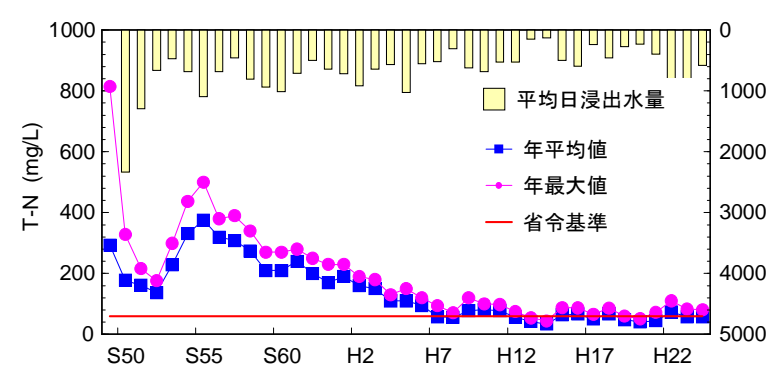

図-1＼cjkstart浸出水の全窒素濃度T-Nの経年变化

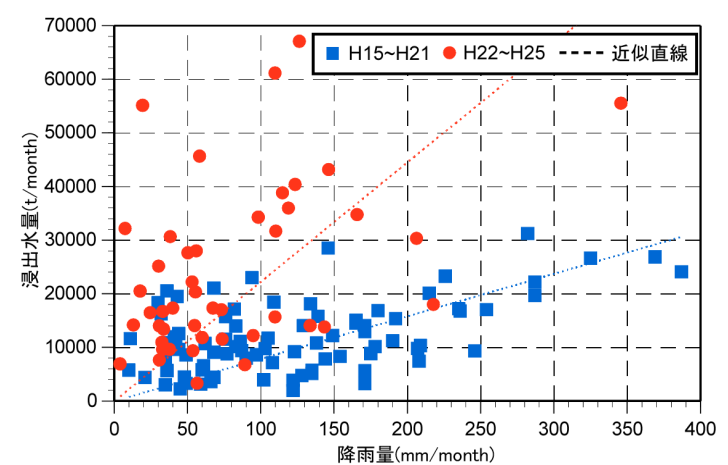

図-2＼cjkstart降雨量に対する浸出水量（流出率）

は硝化・脱窒法で一般的に用いられるメタノールの連続 添加によって炭素を人為的に補給している。 しかし，廃 棄物埋立地の場合には，下水処理場とは異なって埋立事 業が終了した後の排水管理であるため, 維持管理に要す る人材や費用を継続的に確保することは困難である．本 研究では, 常温時に固体で人為管理を経ずに炭素が自然 に徐放される高級脂肪酸素材として，水素徐放剤を脱窒 用炭素源として利用することを検討した. 高級脂肪酸を 脱窒に利用した研究事例として, 村澤ら ${ }^{5}$ は高級脂肪酸 をコーティングした板状のスポンジを実験水路に配置し て脱窒効果を検討している. 李らの的硝酸態窒素で污染 された地下水や水路を対象に高級脂肪酸の他にポリ乳酸 やおがくずを用いた原位置浄化を試みた。著者らは脱窒 の律速要因として, 浸出水の負荷流量, リン, 水素徐放 剂の反応表面積などの影響を実験》で明らかにした。水 素徐放剂の脱窒に対寸る一定の効果が確認されたが，対 象とする実機での水素徐放剤の必要量を概算すると, 経 済的に実現困難であることが判明した，そこで，本研究 では，一定の脱窒効率を備えながら低廉な代替炭素源で あることを条件として，再利用資源のビール粕・固化油 の利用を考え, 浸出水の脱窒効率に関する室内実験を実 施し, 代替炭素源としての性能を水素徐放剂と比較した.

\section{2. 実験方法}

\section{（1）検討対象とする炭素源}

写真-1 3に検討対象の炭素源を示す.

(a) 水素徐放剂

水素徐放剤（アムテクリーンN：Panasonic,TR-

AMNO101）はステアリン酸, パルミチン酸, ミリスチ ン酸（分子式: $\mathrm{C}_{18} \mathrm{H}_{36} \mathrm{O}_{2}, \mathrm{C}_{16} \mathrm{H}_{32} \mathrm{O}_{2}, \mathrm{C}_{14} \mathrm{H}_{28} \mathrm{O}_{2}$ ) を素材
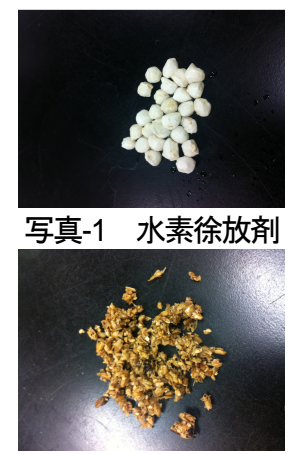

写真-2 ビール粕

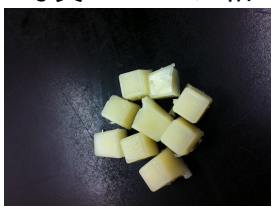

写真-3 固化食用油

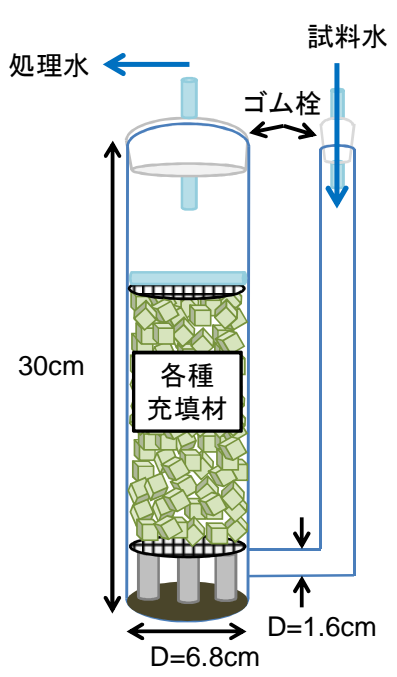

図-3 実験装置
とし, 組成構成比は $\mathrm{C}_{18}: \mathrm{C}_{16}: \mathrm{C}_{14}=65: 30: 5$ である.こ れを湯煎・溶融して綿球に付着させ浸出水の脱窒に利用 する. 平均粒径は約 $0.65 \mathrm{~cm}$ である. 著者らは既に水素徐 放剂の脱窒速度を確認4) 7しており, 本研究ではこれを 参照ケースと位置づける.

(b) ビール粕

大麦の穀皮が主体であり，ビール醸造工程により排出 される.ビール粕自体は有機物であることに加え，リン， カルシウム，マグネシウムなど豊富なミネラルを多く含 むため微生物の馴致を促進して脱窒促進効果の早期発現 が期待できる. ビール粕は家畜飼料として一部再利用さ れているが，食品産業廃棄物であり新たに費用が発生し ない循環資源である。試験水槽への充填に際しては流 出・散冕しないようにストッキングに包んだ.

(c) 固化食用油 (以後, 固化油と記す)

資源循環利用のために廃食用油を想定し，もっとも広 く使われる菜種油を採用した. 菜種油には高級脂肪酸 (主としてオレイン酸, リノール酸, $\alpha$ リノレン酸 : $\mathrm{C}_{18} \mathrm{H}_{34} \mathrm{O}_{2}, \mathrm{C}_{18} \mathrm{H}_{32} \mathrm{O}_{2}, \mathrm{C}_{18} \mathrm{H}_{30} \mathrm{O}_{2}$ ) が含まれているため, ア ムテクリーンと同様の脱窒促進効果を期待できる. 廃食 用油は供給量の多い循環資源でもある. 素材は液体でそ のままでは脱窒処理では取り扱い難いため, 市販されて いる植物由来の廃油処理剂（固めるテンプル：ジョンソ ン）を添加して固化させた.

\section{(2) 実験条件}

図-3の実験容器に, 浸出水貯留池から採取した底泥 $10 \mathrm{~g}$, 各種充填材, 試料水を投入し, 微生物の馴致のた めに24時間静置した. その後, 浸出水を負荷流量 $1.0 \mathrm{ml} / \mathrm{min}$ で通水し，DOや窒素などが安定し平衡状態に 達したと考えられる時点で, 適宜, 流量を $2.0,4.0 \mathrm{ml} / \mathrm{min}$ に切り替えて浸出水負荷量を段階的に増加させた. ここ では, 充填材, 微生物を一定条件に維持した同一容器每 の実験群をtrack と総称する. 実験条件を表-1に示す.

試料水は浸出水処理施設内の散水ろ床塔から採取した 
表-1 実験条件

\begin{tabular}{|c||c|c|c|}
\hline \multicolumn{1}{|c||}{} & track1 & track2 & track3 \\
\hline \hline 試料水 & \multicolumn{3}{|c|}{ 硝化水* + リン** } \\
\hline 炭素源 & 水素徐放剤 & $\begin{array}{c}\text { ビール粕 }+ \\
\text { ガラス球 }\end{array}$ & 固化食用油 \\
\hline 炭素源表面積 & $2000\left(\mathrm{~cm}^{2}\right)$ & 不明***** & $2000\left(\mathrm{~cm}^{2}\right)$ \\
\hline 実験期間 & \multicolumn{2}{|c|}{$2012 / 10 / 24 ~$} & $2012 / 12 / 6 \sim$ \\
\hline
\end{tabular}

* 処理施設内の散水ろ床塔から採水. $\mathrm{NH}_{4}-\mathrm{N}$ が硝化され, 窒素の主成分は $\mathrm{NO}_{3}-\mathrm{N}$ ** 脱窒を促進させるために, 硝化水中の窒素の重量に対し $2 \%$ 添加寸る。

**** 形状不均一のため $100 \mathrm{~g}$ 充填する.

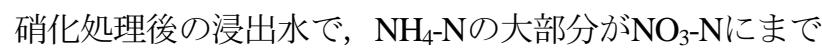
酸化され， $\mathrm{NO}_{3}-\mathrm{N}$ を主成分とする（全有機炭素濃度 TOC : 10〜20mg/程度）. 以後，これを「硝化水」と記 す. 反応促進には水中の窒素に対して重量比 $1 \%$ 程度の リンが必要である8). 硝化水にはリンがほとんど含まれ ておらず，本実験ではリンの律速を受けないように約 2\%のリンを添加した. 水素徐放剂, 固化油の表面積は $2000 \mathrm{~cm}^{2}$ に統一したが，ビール粕は形状不均一であり， $100 \mathrm{~g}$ を充填した. 実験開始3日後, ビール粕の充填が過 密であったために通水性が低下し, 改善策としてガラス 玉（粒径：約 $0.49 \mathrm{~cm} ） 1,000$ 個を混入させて通水性を確 保した. track1，2は2012年10月24日より，track3のみ2012 年12月6日より通水を開始し，2013年2月1日に実験を終 了した. 実験容器を通過した処理水を定期的に採取し, 多項目水質計（堀場製：D-55）による水温， $\mathrm{pH}, \mathrm{DO}$ の 測定と $\mathrm{NO}_{3}-\mathrm{N}, \mathrm{NO}_{2}-\mathrm{N}, \mathrm{NH}_{4}-\mathrm{N}, \mathrm{PO}_{4}-\mathrm{P}, \mathrm{T}-\mathrm{N}, \mathrm{TOC}$ 濃 度を計量分析した。 34日目から実験室の空調設備が故 障・停止して外気温の季節変化とともに水温が低下した. そのため，全trackで脱窒が低調となった．56日目より実 験装置内の水温を制御するため, ヒーターで水温を $30^{\circ} \mathrm{C}$ に維持した恒温水槽に全trackの実験水槽を浸漬させた.

\section{3. 実験結果と考察}

\section{(1) 各水質濃度の時系列変化}

図-4にtrack1の各窒素濃度と水温の時系列を示寸。流 入水中の $\mathrm{T}-\mathrm{N}$ と比べて処理水のT-Nは減少し, 脱窒が確 認される. 実験開始直後に $\mathrm{NO}_{2}-\mathrm{N}$ している。 これは， $\mathrm{NO}_{3}-\mathrm{N} \rightarrow \mathrm{NO}_{2}-\mathrm{N}$ の反応を担う脱窒菌 が馿致した後に, $\mathrm{NO}_{2}-\mathrm{N} \rightarrow \mathrm{N}_{2}$ の反応を担う脱窒菌の馴致 が遅れて開始するためであると考えられる．負荷流量 $1.0 \mathrm{ml} / \mathrm{min}$ ではT-Nが $10 \mathrm{mg} / 1$ 以下, $2.0 \mathrm{ml} / \mathrm{min}$ では $20 \mathrm{mg} /$ 以 下と，実験開始後34日目までは脱窒が堅調に推移した.

しかし, 空調停止後は季節進行とともに水温が低下した ため微生物活動が低調となり，T-Nの残留が増えた. 56 日目以降の恒温水槽による水温制御後は脱窒効率が回復 し, 水温制御前に比べると T-Nが $10 \mathrm{mg} /$ 程度減少した. このことからも, 脱窒において水温が非常に重要な律速 因子であることが再確認される。

図-5にtrack2の各窒素濃度とTOC濃度の時系列を示す。

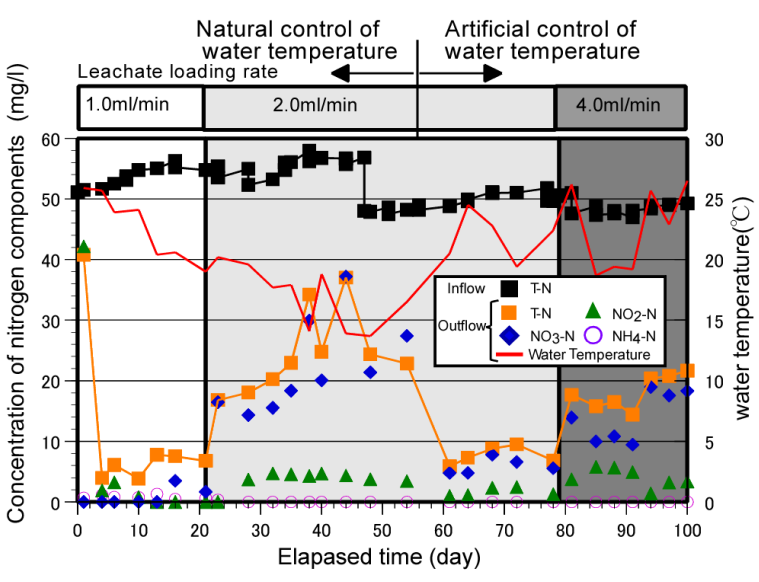

図-4 track1における水質濃度と水温の時系列

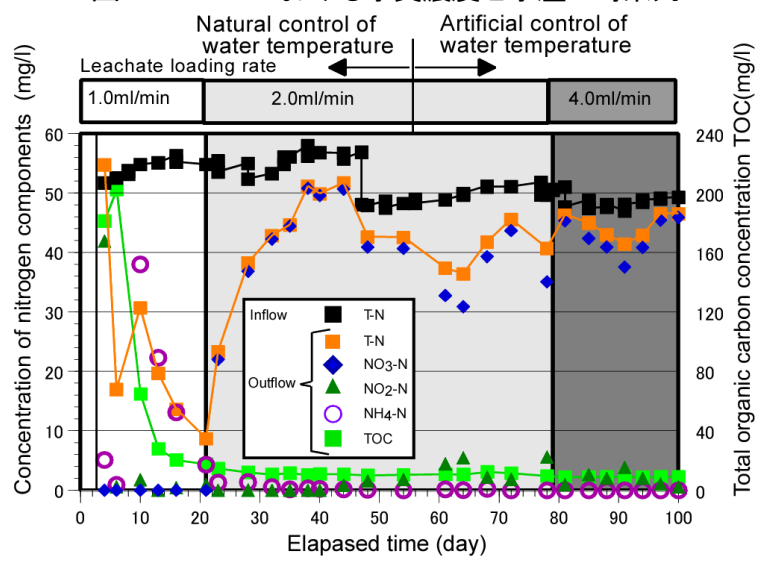

図-5 track2における水質濃度（TOCを含む）の時系列

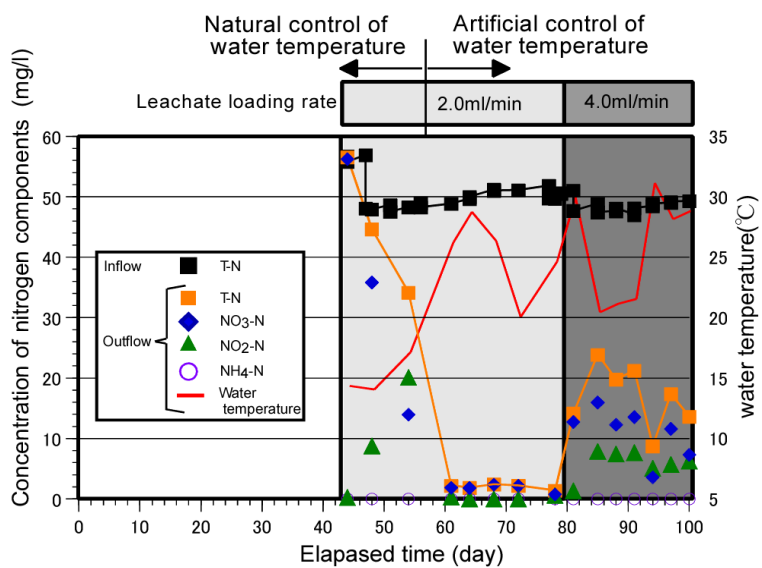

図-6 track3における水質濃度と水温の時系列

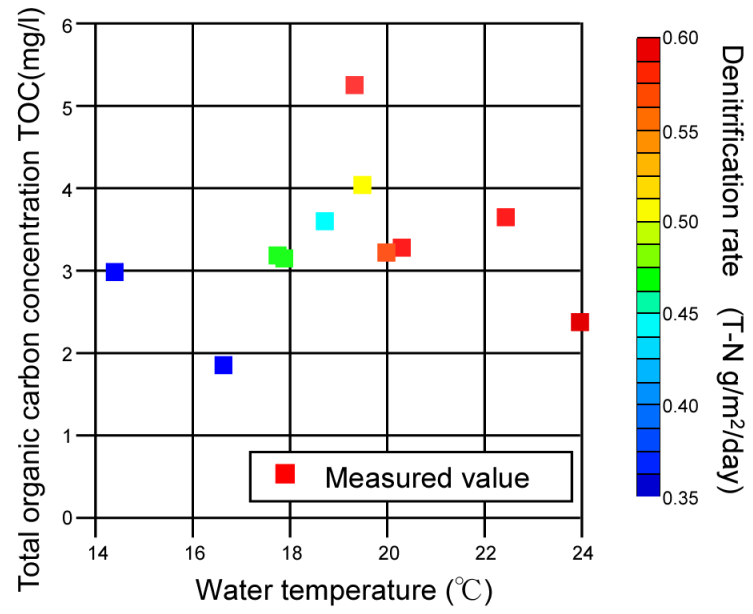

図-7 水温とTOCが脱窒速度に及ぼす影響（track1） 
track1 と同様の理由により, 実験開始直後における $\mathrm{NO}_{2}-$ Nの増加が確認される． $\mathrm{NH}_{4}-\mathrm{N}$ は，約20日目まで連続的

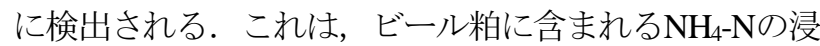
出によると考えられる．20日目以降， $\mathrm{NH}_{4}-\mathrm{N} の$ 検出がな

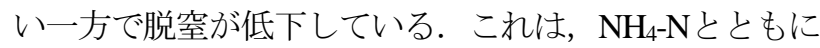
浸出していたビール粕内のTOCが枯渇し, 脱窒菌への供 給が不足したためであると考えられる。しかし，TOCが 枯渇した後も，低調ではあるもののT-N濃度が5 10mg/1 程度減少していることから, 負荷流量に応じてビール粕 を充填すれば，循環資源を利用した経済的な脱窒を実現 できる可能性がある.

図-6にtrack3の各窒素濃度と水温の時系列を示す. $\mathrm{NO}_{2}-\mathrm{N}$ が完全に消失するまでの馴致期間は20日程度であ り，他のtrackよりも長い。これは，水素徐放剤に比べて 固化油の平均炭素数が高いために, 溶出・分解能が低く 脱窒菌に利用されにくいことが原因と考えられる．脱窒 菌が馴致した後には，負荷流量 $2.0 \mathrm{ml} / \mathrm{min}$ 時にT-N=5mg/l, $4.0 \mathrm{ml} / \mathrm{min}$ 時にはT-N=20mg/l程度の窒素が残留し, 水素 徐放剂と同程度の高い脱窒効率を発揮した。しかし，固 化油から溶出したTOCの余利分により処理水が白濁して いた. ビーカーに $200 \mathrm{ml}$ の白濁処理水を採取して24時間 曝気を実施することで白濁が消滅したため易分解性有機 物であると考えられる.

\section{(2) 水温とTOC濃度が脱窒速度に及ぼす影響}

空調設備の故障と水温制御の再開などで水温が実験期 間内に変動したために，水温が脱窒に及ぼす影響を確認 することができた．図-7にtrack1における水温とTOC濃 度と単位担体表面積あたりのT-Nの時間低減率（以後, 脱窒速度と記す）の関係を示す。なお，負荷流量が脱窒 速度に及ぼす影響を排除して比較を行うために，負荷流 量 $2.0 \mathrm{ml} / \mathrm{min} の み の$ 結果を示している. ここで, TOCの評 価に際しては，流出水と流入水のTOCの差をとり，難分 解性有機物を除く脱窒菌が利用可能な易分解性成分だけ を計量している. 図-7から水温の上昇にともなう脱窒速 度の増加が見られるが，水温とTOCに有意な関係性は見 出せない（図-4にTOCの計測值を示していないのはこの 理由による）。この原因として，水温上昇によって有機 物の溶出量が増加するものの，水温上昇とともに活性化 した脱窒菌が相応の有機物を消費し，TOCがほとんど増 減せず同程度の水準で推移したと考えられる.

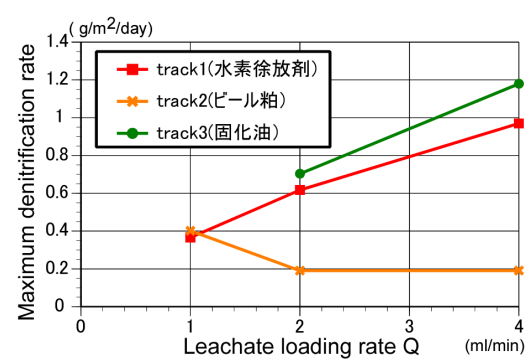

(a) 最大脱窒速度

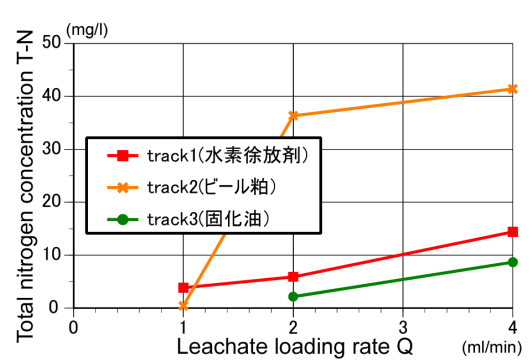

(b) 全窒素濃度T-N

\section{（3）浸出水負荷量が脱窒速度に及ぼす影響}

脱窒菌の活性は，脱窒の材料であるT-NやTOCを含む 浸出水の負荷量に依存する. 図-8に負荷流量と脱窒速度, T-N，TOCの関係を示す. 負荷量と脱窒速度との関係を 見ると（図-8(a)），負荷流量が $1.0 \mathrm{ml} / \mathrm{min}$ と小さい場合に はT-Nのほぼ全量が除去されており， track間の差異は見 受けられない. 例えば, 図-8(b)を見ると，T-Nの残留濃 度が5mg/l以下と低く, 窒素材料の不足によって脱窒が 律速を受けていることがわかる. 負荷流量を $2.0 \mathrm{ml} / \mathrm{min}$, 4.0ml/minにまで増加させると, track1, 3では窒素不足が 解消されて脱窒速度が回復したのに対し， track2では低 下した．当然のことながら，T-N負荷が増加すると増分 相当のTOCが消費される. track1，3では炭素源からの易 分解性有機物の供給が十分であり TOCの律速を受けずに T-N負荷とともに脱窒速度が増加するのに対し, track2で は脱窒に要する易分解性有機物の供給が不十分であるた めにTOCの律速を受けて脱窒速度が低下寸る．以上が， 上記のような結果の原因と考えられる.このことは，図 -8(c)に示すように, 負荷流量の増加とともに残留TOC濃 度が減少していることからも確認される。この結果は, T-N負荷と易分解性有機物の溶出量がバランスする負荷 流量の下で, 脱窒効率の極大值が出現する可能性を示唆 している. 寸なおち，［窒素負荷（負荷流量），炭素供 給量]の最適組み合わせによって脱窒効率を最大化でき る可能性がある.

本実験結果に基づき，各炭素源の脱窒促進性能が以下 のように総括される. ビール粕の炭素溶出期間は短いた め，一定の脱窒能力を継続するために定期的な補充が必 要である. 固化油は水素徐放剤と同程度の脱窒能力を示 す.しかし, 固化油から溶出したTOCの余剒分により処 理水が白濁する. 曝気により白濁が消滅したため, 適切 な後処理を施せば固化油の実用化があり得る。水素徐放 剤の脱窒効果は安定しているが，冒頭に述べたように， 実用化には経済上の課題が残されている.

\section{4. 脱窒過程の水質モデル}

\section{(1) 水質モデルの概要}

浸出水処理施設の諸元を決める上で必要な水素徐放剂 の量や最適流量などを推算するために脱窒過程の水質モ デルを構築した. ここでは，安定な脱窒効果を発揮する 水素徐放剂を炭素源に用いた場合の解析例を示寸. 生物

図-8 負荷流量と各項目との関係

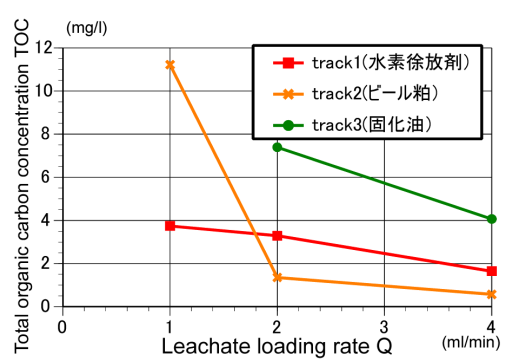

(c)全有機炭素濃度TOC 
化学的反応による水質濃度 $x$ の時間変化量は次式であら わされる。

$$
\frac{d x}{d t}=S(x)
$$

ここで， $t$ : 時間, $S(x)$ : 水質項目 $x$ に関する反応収支であ る. 反応には微生物が介在し, 酵素反応に適用される Michaelis-Menten型の反応速度式を採用する.

流出入負荷の影響は，以下の連続式により記述される。

$$
x_{\mathrm{t}+1}=\frac{\left(x_{\mathrm{t}}+S(x) \cdot d t\right) \cdot(V-Q \cdot d t)+x_{\mathrm{in}} \cdot Q \cdot d t}{V}
$$

ここで， $x_{\mathrm{t}}$ : 時刻 $t$ こおける各水質濃度， $x_{\mathrm{t}+1}: t$ 小らdt時間 後の各水質濃度, $S(x)$ : 反応槽における濃度変化率, $V$ : 反応槽容積, $Q$ : 流入量, $x_{\text {in }}$ : 流入濃度である.

\section{(2) 各水質項目の収支式}

本モデルでは硝酸態窒素 $\mathrm{NO}_{3}-\mathrm{N}$ ，リン酸態リン $\mathrm{PO}_{4}-\mathrm{P}$, 浸出水に元々含まれる難分解性有機物濃度 $\mathrm{C}_{\text {or }}$, 水素徐 放剂から溶出した易分解性有機物濃度 $\mathrm{C}_{\text {amte }}$ ，溶存酸素濃 度DOの5つの水質項目之脱窒菌濃度 $\mathrm{B}_{\mathrm{ND}}$, 有機物酸化菌 濃度 $\mathrm{B}_{\mathrm{CC}}$ の $2 つ$ 微生物項を定式化した。一例として, $\mathrm{NO}_{3}-\mathrm{N}$ の収支式 $S\left(\mathrm{NO}_{3}\right)$ は以下のようにあらわされる.

$$
\begin{aligned}
S\left(N O_{3}\right)= & -R_{\mathrm{ND}} \cdot f_{\mathrm{ND}}(T) \cdot \frac{D_{\mathrm{ND}}}{D_{\mathrm{ND}}+D O} \cdot \frac{N O_{3}}{C_{\mathrm{ND}}+N O_{3}} \cdot B_{\mathrm{ND}} \\
& \times\left(\phi_{11} \cdot \frac{C_{\text {ori }}}{C_{\mathrm{Co}}+C_{\text {ori }}}+\phi_{12} \cdot \frac{C_{\text {amte }}}{C_{\mathrm{Ca}}+C_{\text {amte }}}\right)
\end{aligned}
$$

ここに $R_{\mathrm{ND}}$ : 基準状態における脱窒速度, $f_{\mathrm{ND}}$ :温度制御関 数 $D_{\mathrm{ND}}: D O$ に関するスイッチ定数, $B_{\mathrm{ND}}$ :嫌気性脱窒菌濃 度, $\mathrm{NO}_{3}$ : 硝酸態窒素濃度, $C_{\text {or }}, C_{\text {ante: }}$ :各有機物濃度, $C_{\mathrm{Co}}$, $C_{\mathrm{Ca}}$ : 各有機物種に対する半飽和定数, $\varphi_{11}, \varphi_{12}$ :各有機物 種に対する分配定数である. 添字NDは脱窒に関する諸 量を, 添字ori, amteは, 有機炭素のうち浸出水由来, 水 素徐放剂由来の成分にそれぞれ対応する. 式(3)中の脱窒 菌濃度 $B_{\mathrm{ND}}$ の増減速度 $S\left(B_{\mathrm{ND}}\right)$ は次のように定式化される.

$$
\begin{aligned}
& S\left(B_{\mathrm{ND}}\right)=f_{\mathrm{BND}}(T) \cdot \frac{D_{\mathrm{BND}}}{D_{\mathrm{BND}}+D O} \cdot \frac{N O_{3}}{C_{\mathrm{BND}}+N O_{3}} \cdot \frac{P O_{4}}{P_{\mathrm{BND}}+P O_{4}} \cdot B_{\mathrm{ND}} \\
& \quad \times\left(R_{\mathrm{BNDori}} \cdot \frac{A}{V} \cdot \frac{C_{\text {ori }}}{C_{\mathrm{NDCO}}+C_{\text {ori }}}+R_{\mathrm{BNDamte}} \cdot \frac{\text { Aamte }}{V} \cdot \frac{C_{\text {amte }}}{C_{\mathrm{NDCA}}+C_{\text {amte }}}\right) \\
& -R_{\mathrm{DBND}} \cdot f_{\mathrm{DBND}}(T) \cdot B_{\mathrm{ND}}
\end{aligned}
$$

ここに $R_{\mathrm{BND} \text { ori }}, R_{\mathrm{BNDamte}}$ 基準状態における各有機炭素に 起因する脱窒菌の増殖速度, $A$ :全接触表面積, $V$ :反応槽 容積, Aamte : 水素徐放剂の表面積, $R_{\mathrm{DBND}}, R_{\mathrm{DBNDO}}$ : 基 準状態における脱窒菌の死滅速度である. 添字BNDはそ れぞれの脱窒菌に関する諸量であることを意味する.

\section{(3) 温度制御関数}

脱窒反応を担う微生物は水温の影響を受け，その好適 水温は $25 \sim 30^{\circ} \mathrm{C}$ と言われている. 本実験では屋外貯留池 で硝化された浸出水を試料水として用いており，資料水 の温度が季節的に変動する．また，前述のようにある実 験期間において不測の空調停止により水温が低下した. 以上のような水温変化が生じたため, 本実験では脱窒が

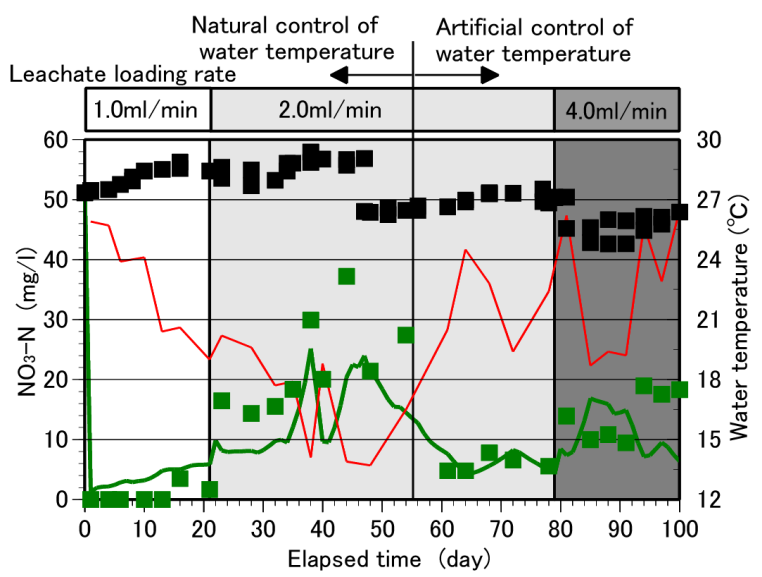

(a) $\mathrm{NO}_{3}-\mathrm{N}$

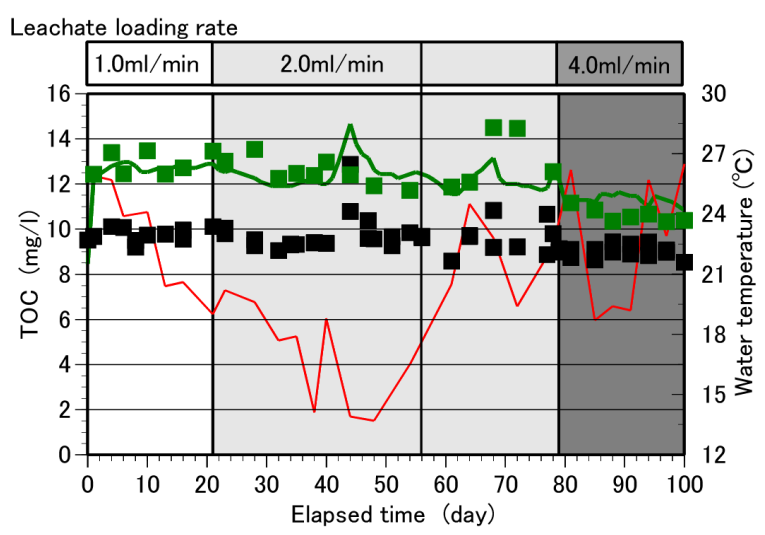

(b) TOC

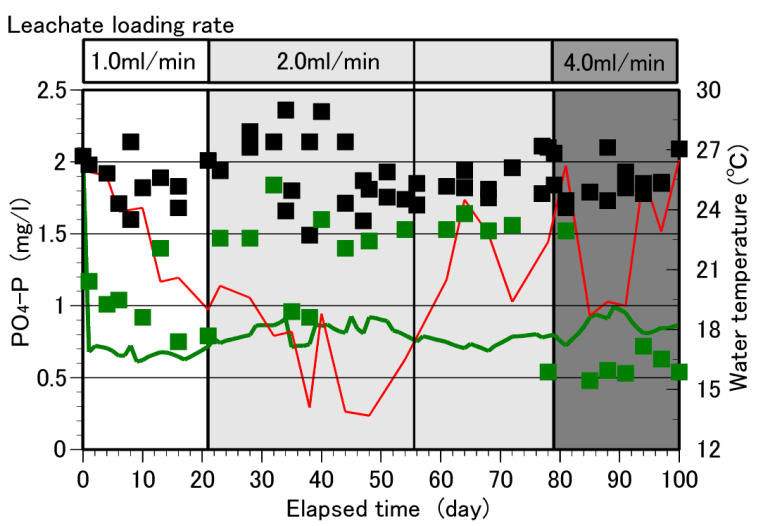

(c) $\mathrm{PO}_{4}-\mathrm{P}$

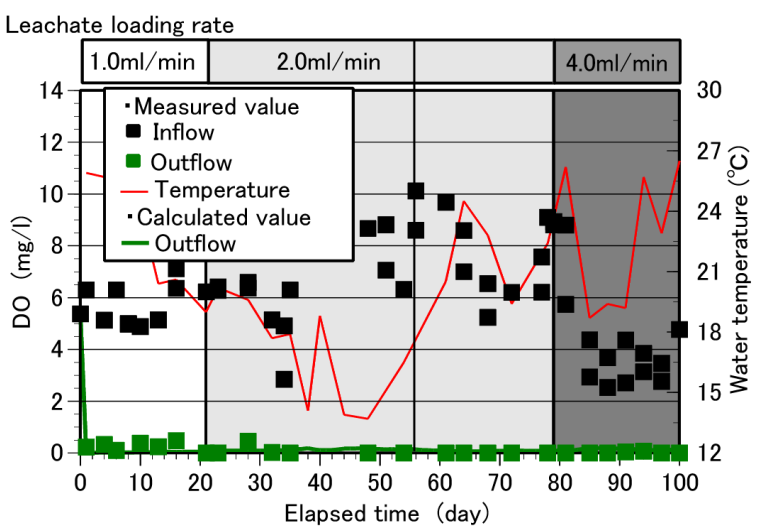

(d) DO

図-9 各水質濃度の実験値と解析值の比較 
水温の律速を受ける可能性が高い。そこで，水温の影響 を脱窒モデルに組み込むために，以下の温度制御関数を 定式化しパラメータを同定した.

$$
f(T)=\theta^{(T-20)}
$$

ここに $\theta:$ 温度補正係数， $T$ : 水温である.

\section{（4）水質解析に基づく考察}

4. で記した脱窒モデルを用いて水質挙動を再現した結 果を図-9に示す．緑色の曲線は解析值で記号は実験值で ある. 赤線は水温で与条件である. "Inflow"は流入条件 として与えられる試料水の諸量であり，比較すべき解析 值はない. 図-9(a)を見ると， $\mathrm{NO}_{3}-\mathrm{N} は$ 実験開始初期の負 荷流量が小さい段階において脱窒により枯渇気味である こと, 負荷流量の段階的増加にともない脱窒が追いつか なくなり $\mathrm{NO}_{3}$-Nの残留量が増加することなど，実験で観 測される窒素の挙動が良好に再現されている，また，空 調停止により水温が低下した際には脱窒が減速し, 恒温 水槽を用いて水温制御を開始すると脱窒速度が回復する など, 水温にともなう脱窒の律速状況が温度制御関数に よって良好に再現されている.

図-9(b)のTOCを見ると，実験では流量増加にともない 炭素源から溶出した有機物が希釈されてTOCが減少して いる. 解析でもこのようなTOCの挙動が良好に再現され ている.

図-9(c)にはPO4-Pの経時変化を示す. $\mathrm{PO}_{4}-\mathrm{P}$ は微生物の 菌体を構成する元素の一つであり，本モデルでは微生物 の増殖に連動して消費されるように定式化されている. 過去の実験によれば9), 負荷量に応じて微生物の馴致が 進み一定の微生物量に落ち着くことや，負荷流量の増加 にともない水素徐放剤表面との接触時間が減少して微生 物による $\mathrm{PO}_{4}-\mathrm{P}$ の消費が減少して $\mathrm{PO}_{4}-\mathrm{P}$ の残留量が増える ことが確認されている. しかし，本実験では，負荷流量 が2.0, $4.0 \mathrm{ml} / \mathrm{min}$ と増加するにともない $\mathrm{PO}_{4}-\mathrm{P}$ の消費量が むしろ増加するなど, 過去の実験とは異なる挙動を示し ている.この点について解析結果と大きく乘離しており, 実験における $\mathrm{PO}_{4}-\mathrm{P} の$ 挙動を解明し，パラメータを適切 に調整することで再現性を向上させる必要がある.

図-9(d)のDO時系列では，解析・実験ともに流入濃度 に依らず速やかに消費されており，ほぼ0mg/lの嫌気的 環境が維持されている.

\section{5. まとめ}

メタノールに代わる炭素源として水素徐放剤, ビール 粕，固化食用油を流水系力ラムに充填し，浸出水の脱窒 性能を確認した. 本研究で得られた知見を要約する.

(1)水素徐放剂を用いたtrackでは負荷流量を増加させるに つれて脱窒速度が増加する.さらに負荷流量を増加させ ると，ある最適な負荷流量の下で脱窒速度が極大值をと ると推察される. 本実験で確認された最大脱窒速度は負 荷流量 $4.0 \mathrm{ml} / \mathrm{min}$ の時の $0.97 \mathrm{~g} / \mathrm{m}^{2} /$ dayであった.

(2)ビール粕の場合には脱窒の進行が確認され，ビール粕 が脱窒の炭素源として利用できることは間違いないが, 新鮮なビール粕には $\mathrm{NH}_{4}-\mathrm{N} か ゙$ 含有されており, その溶出
によって初期段階に一時的な窒素負荷をもたらす。ビー ル粕に含有される $\mathrm{NH}_{4}-\mathrm{N}$ 脱窒槽への投入前に除去する などの前処理を施すことと, TOCが枯渇しないように ビール粕を持続的に補填供給することが実機に応用する 場合の課題である.

(3)固化食用油はビール粕よりも炭素源の持続性と脱空性 能に優れた代替炭素源であるが，余剰炭素の白濁を緩和 するために曝気などの後処理を併用するのがよい.

(4)脱窒過程の水質モデルを構築し, 本実験で計測された $\mathrm{NO}_{3}-\mathrm{N}, \mathrm{TOC}, \mathrm{PO}_{4}-\mathrm{P}, \mathrm{DO}$ の時間変化挙動を再現した. 微生物の新陳代謝にともなう脱窒反応が解析によって良

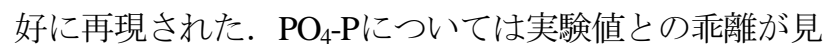
られ水質モデルの課題を残した.

(5)脱窒反応の温度依存性は高く, 水質解析に適切な水温 制御関数を組み込むことが重要であることを確認した.

また，脱窒反応における $\mathrm{PO}_{4}-\mathrm{P} の$ 役割を無視することは できないが，本解析では $\mathrm{PO}_{4}-\mathrm{P} の$ 再現性は必ずしも十分 でなく， $\mathrm{PO}_{4}-\mathrm{P}$ 収支に関わる生物化学的収支について検 討する余地が残された。

\section{謝辞}

本論文の作成にあたり，神戸大学大学院の大石哲教授に は適切で熱心なご指導を賜った. 記して謝意を表する.

\section{参考文献}

1) 福永勲 : 窒素・燐に係わる環境水の現状と水処理技術の最近 の進歩, 生活衛生, Vol.38, No.5, pp221-244, 1994.

2) 道奥康治, 釘宮晃一, 山田怜奈, 伊藤義明, 八木正博, 中道 民広 : ゴミ埋め立て処分場からの浸出水のマイクロバブルに よる水質浄化，水工学論文集，第51巻，pp.1403-1408，2007.

3) 道奥康治，山田怜奈，松本敏秀，釬宮晃一，中道民広，伊藤 義明, 八木正博, 原義晴 : 廃棄物堆積層からの浸出水の浄化 処理に関する実証試験, 水工学論文集, 第52巻, pp.12731278, 2008.

4) 和田有朗，中道民広，八木正博，松本敏秀，釘宮晃一，道奥 康治 : 経年化した廃棄物埋立処分場からの浸出水の脱窒処理 に関寸る基礎的検討, 水工学論文集, 第55巻, pp.S_1489S_1494, 2011.

5) 村澤浩一郎, 納村和美, 森崎久雄, 佐野明美, 寺田剛史, 田 井中善雄 : 高級脂肪酸を水素供与体として用いた水路の直接 脱窒, 水環境学会誌 = Journal of Japan Society on Water Environment 25(12), pp737-742, 2002.

6) 李盛源, 田瀬則雄 : 酸化的浅層地下水における硝酸性窒素の 原位置浄化，地下水学会誌，49(2), pp.97-114， 2007.

7) 田中健治, 道奥康治, 中道民広, 八木正博, 和田有朗 : 炭 素・リン・微生物環境ならびに窒素負荷が浸出水の脱窒効率 に及ぼす影響, 土木学会論文集B1（水工学），Vol.68，No4， pp.I_619-I_624, 2012

8) 吉村二三隆 : これでわかる水処理技術, pp.131-140, 工業調 査会, 2002 .

9) 田中大也, 井上晃介, 田中健治, 道奥康治, 八木正博, 中道 民広, 和田有朗 : 種々の炭素源を用いた浸出水の脱窒処理に 関する実験的検討, 土木学会第67回年次学術講演会講演概要 集, VII-023, 2012.

(2014. 9. 30受付) 